\title{
Optimization of Saccharification Conditions of Acid-pretreated Sweet Sorghum Straw Using Response Surface Methodology
}

\author{
Sukanya Phuengjayaem ${ }^{1}$, Aphisit Poonsrisawat ${ }^{1}$, Amorn Petsom $^{2} \&$ Siriluk Teeradakorn ${ }^{3}$ \\ ${ }^{1}$ Program in Biotechnology, Faculty of Science, Chulalongkorn University, Bangkok, Thailand \\ ${ }^{2}$ Department of Chemistry, Faculty of Science, Chulalongkorn University, Bangkok, Thailand \\ ${ }^{3}$ The Institute of Biotechnology and Genetic Engineering, Chulalongkorn University, Bangkok, Thailand \\ Correspondence: Siriluk Teeradakorn, The Institute of Biotechnology and Genetic Engineering, Chulalongkorn \\ University, Bangkok 10330, Thailand. Tel: 66-2218-8073. E-mail: tsiriluk@chula.ac.th
}

Received: December 25, 2013 Accepted: July 6, 2014 Online Published: August 15, 2014

doi:10.5539/jas.v6n9p120 URL: http://dx.doi.org/10.5539/jas.v6n9p120

\begin{abstract}
This study focused on the cellulase production from $C$. versicolor TD17, white rot fungi. The maximum cellulase activity of $0.897 \mathrm{U} / \mathrm{ml}$ was obtained after 5 days of cultivation using $20 \mathrm{~g} / \mathrm{l}$ cellobiose as a carbon source and $2 \mathrm{~g} / \mathrm{l}$ ammonium sulfate supplemented with $0.3 \mathrm{~g} / 1$ urea as nitrogen sources. Enzymatic saccharification of acid-pretreated sweet sorghum straw (SSS) using in house cellulase was optimized using Response Surface Methodology (RSM), variable five-code-level, four-factor; $1.0-7.0 \% \mathrm{w} / \mathrm{v}$ acid-pretreated SSS, $15-35 \mathrm{FPU} / \mathrm{g}$ dry substrate of cellulase enzyme, $\mathrm{pH} 3$ to 7 and temperatures 30 to $70{ }^{\circ} \mathrm{C}$. The optimal conditions were $1 \% \mathrm{w} / \mathrm{v}$ acid-pretreated SSS, $25 \mathrm{FPU} / \mathrm{g}$ dry substrate of cellulase, $\mathrm{pH} 5,50{ }^{\circ} \mathrm{C}$ and $72 \mathrm{~h}$ cultivation. A maximal glucose yield of $0.440 \mathrm{~g} / \mathrm{g}$ dry substrate was obtained.
\end{abstract}

Keywords: saccharification, acid pretreatment, sweet sorghum straw, response surface methodology

\section{Introduction}

The industrial revolution has generated an increasing need for energy. Petroleum was in great demand and its use has been spread, therefore, rapid price rising of petroleum-based fuels have recently increased. As a consequence, ethanol production as an alternative to petroleum-based fuels can be produced from biomass, a plentiful renewable resource. To increase the productivity and cost effectiveness of ethanol production, lignocellulose is one of potential choices due to sufficient abundance and generating very low net greenhouse emissions (Ikeda et al., 2007). It reduces carbon monoxide emission by blending bioethanol into gasoline. Apart from sugarcane (in Brazil), corn grain (in USA), tapioca starch and sugarcane molasses (in Thailand), other agricultural raw materials rich in fermentable carbohydrates, including sorghum, have been of particular interest for biological transformation into ethanol for use as fuel or fuel additive (Laopaiboon et al., 2009).

Sweet sorghum (Sorghum bicolor (L.) Moench) is a tropical grass that can be cultivated in nearly all temperatures and in a wide range of tropical climates. Sweet sorghum is a drought-resistant agricultural crop that can remain dormant during dry periods because it is tolerant of water-logging, salinity and alkalinity. Sweet sorghum is also reported to remain dormant under more favorable environmental and nutritional conditions (Laopaiboon et al., 2009). Sweet sorghum is an inexpensive and abundant renewable cellulose resource that can be synthetically used in additives as a raw material for ethanol production and has byproducts with high additional value. This grain's stalk has high polysaccharide content comprised of cellulose and hemicellulose. Cellulose is a major fraction of lignocellulosic biomass that can be hydrolyzed to glucose by cellulase enzymes. The natural structure of this biomass makes it difficult for microorganisms to utilize these components to produce ethanol.

The main processes of lignocellulose biomass to ethanol conversion consist of pretreatment, enzymatic hydrolysis (saccharification) and ethanol fermentation. Saccharification is a critical step for sugar production. The pretreatment breaks the lignin seal and alters substrate composition, which is essential for lignin removal, hemicellulose pre-hydrolysis, cellulose crystallinity reduction, and increasing lignocellulosic material porosity. Pretreatment significantly improves sequential enzyme attack for maximal sugar productivity. Pretreatment methods such as $\mathrm{H}_{2} \mathrm{SO}_{4}$ or $\mathrm{HCl}$ treatment give high hemicellulose sugar recovery in the liquid fraction with most 
of the cellulose remaining in the solid residue for sequential enzymatic saccharification (Qi et al., 2009). Enzymatic saccharification is the second step in ethanol production from cellulosic material. The main hydrolysis product of cellulose is glucose, whereas hemicellulose yields pentoses and hexoses. Cellulases are key enzymes for bioconversion of cellulosic biomass to useful products. Enzyme saccharification activity is important to produce reducing sugars from cellulosic biomass, especially glucose. This ability is influenced by enzyme component composition (Ikeda et al., 2007). A complete cellulase system consists of three extracellular enzymes that are required for complete cellulose breakdown to simple sugars. The cellulase system contains Endoglucanase (EG), Exoglucanases and $\beta$-glucosidases (BGL). Cellulase production is the most important step in achieving economical ethanol production from renewable cellulosic material. Cellulolytic enzyme components are different in each microorganism species. Many microorganisms that produce various cellulolytic enzymes have been studied for several decades; e.g., fungi, bacteria and actinomycetes. Most commercial cellulase production research has focused on fungi, such as Trichoderma reesei, Aspergillus niger and Penicillium brasilianum. Of these fungal genera, the well-studied Trichoderma reesei fungus has been famous for producing commercial cellulolytic enzymes with relatively high enzymatic activity. However, Trichoderma enzymes do not effectively hydrolyze cellulose biomass alone (Sun \& Cheng, 2002) because low $\beta$-glucosidase activity is produced relative to the total cellulase activity, which is inhibited by glucose. Because inhibiting the product of BGL controls saccharification, enzymatic hydrolysis efficiency cannot be improved much by increasing enzyme loading, and high enzyme amounts are added for saccharification (Sukumaran et al., 2009). White-rot fungus is an interesting use for lignocellulose degradation because of its ability to degrade all lignocellulosic material components completely. A statistical approach was applicable to improve enzymatic saccharification process performance and develop more economical cellulolytic enzyme production (Levin et al., 2008). Enzymatic saccharification efficiency depends on several process parameters, such as enzyme loading, substrate concentration, temperature and $\mathrm{pH}$, which often interact with one another. Traditional methods for optimizing a multifactorial system include dealing with "one-factor-at-a-time," which involves changing one independent variable while fixing other variables to investigate an individual factor's influence on process performance. This "one-factor-at-a-time" method ignores interactions among different factors, and has been criticized for having little chance of finding optimal conditions. This single-dimensional search is laborious, time-consuming, expensive and incapable of reaching a true optimum because it does not estimate interactions among experimental variables. A statistical method was recently used as an alternative and more efficient approach. Response surface methodology (RSM) was applied to identify optimal conditions for reducing sugar production from enzyme saccharification of pretreated sweet sorghum straw by analyzing the effect of multiple variables on overall process speed and efficiently with minimal experiments while ensuring a high degree of statistical significance in the results (Qi et al., 2009; Levin et al., 2008; Jeya et al., 2010).

In this study, enzymatic saccharification of acid-pretreated sweet sorghum straw was investigated using cellulolytic enzyme from Coriolus versicolor TD17 compared with commercial cellulase from Trichoderma reesei. Moreover, optimal saccharification conditions were studied using the RSM method.

\section{Method}

\subsection{Fungal Strain and Culture Conditions}

Coriolus versicolor TD17 was kindly offered from Emeritus Professor Yataka Kitamoto, Japan. The fungal strain was maintained in potato dextrose agar at $4{ }^{\circ} \mathrm{C}$. Small pieces $\left(20-40 \mathrm{~mm}^{2}\right)$ of mycelium without agar were cultured on a fresh, sterile potato dextrose agar (PDA) slant for 10 days at $30{ }^{\circ} \mathrm{C}$ before being aseptically transferred to a $250 \mathrm{ml}$ Erlenmeyer flask containing $50 \mathrm{ml}$ potato dextrose broth (PDB). Initial media $\mathrm{pH}$ was adjusted to 5.0 with either $1 \mathrm{~N} \mathrm{NaOH}$ or $\mathrm{HCl}$. The media was then autoclaved for 20 min at $121{ }^{\circ} \mathrm{C}$. Cultivation conditions were $30{ }^{\circ} \mathrm{C}$ with $150 \mathrm{rpm}$ shaking for $48 \mathrm{~h}$. Next, $10 \% \mathrm{v} / \mathrm{v}$ submerged culture was used as the inoculum for cellulase production.

\subsection{Cellulase Production From Coriolus versicolor TD17}

Basal media composition for cellulase production was based on Mandel's method (Mandels, 1975). The culture media contained $20 \mathrm{~g} / 1$ carboxymethylcellulose (CMC), $3.0 \mathrm{~g} / 1$ ammonium sulfate, $1.0 \mathrm{~g} / 1$ peptone, $0.3 \mathrm{~g} / 1$ urea, $2.0 \mathrm{~g} / 1$ potassium di-hydrogen phosphate, $0.5 \mathrm{~g} / 1$ magnesium sulfate, $1.0 \mathrm{~g} / 1$ tween- 80 and $2.0 \mathrm{ml} / 1$ trace metal solution. The trace metal solution contained $2.5 \mathrm{~g} / 1$ ferrous sulfate, $0.8 \mathrm{~g} / \mathrm{l}$ manganese sulfate, $0.7 \mathrm{~g} / \mathrm{l}$ zinc sulfate and $1.0 \mathrm{~g} / \mathrm{l}$ cobalt chloride, $\mathrm{pH} 4.0$. Media was sterilized by autoclaving at $121{ }^{\circ} \mathrm{C}$ for $15 \mathrm{~min}$. The crude filtrate from the cultivation culture was used as crude cellulase in enzymatic saccharification studies.

\subsection{Effect of Carbon Sources on Cellulase Production}

Different carbon sources were studied using basal media supplemented with either $20 \mathrm{~g} / \mathrm{l}$ of 
carboxymethylcellulose, cellobiose, avicel, or $\alpha$-cellulose as the sole carbon source for the optimization experiment.

\subsection{Effect of Nitrogen Sources on Cellulase Production}

Different nitrogen sources were studied using basal media supplemented with either $4 \mathrm{~g} / 1$ ammonium sulfate, ammonium nitrate, peptone, yeast extract, urea or control nitrogen sources (ammonium sulfate, peptone and urea) for the optimization experiment.

\subsection{Effect of Combined Nitrogen Sources on Cellulase Production}

The influence of each nitrogen source (ammonium sulfate, peptone and urea) was investigated using basal media in which a single nitrogen source was taken from the production media and compared with only ammonium sulfate as a nitrogen source and control media that contained three nitrogen sources as shown in Table 1.

Table 1. Various nitrogen sources in the culture media

\begin{tabular}{cccc}
\hline \multirow{2}{*}{ Abbreviation } & \multicolumn{3}{c}{ Nitrogen sources } \\
\cline { 2 - 4 } & $\left(\mathrm{NH}_{4}\right)_{2} \mathrm{SO}_{4}$ & Peptone & Urea \\
\hline $\mathrm{NPU}($ control $)$ & + & + & + \\
$\mathrm{N}$ & + & - & - \\
$\mathrm{NP}$ & + & + & - \\
$\mathrm{NU}$ & + & - & + \\
\hline
\end{tabular}

\subsection{Sweet Sorghum Straw Pretreatment}

Sweet sorghum straw (SSS) was obtained from The Suphanburi Field Crops Research Center in Thailand. The SSS consisted of $44.51 \%$ cellulose, $38.62 \%$ hemicellulose, $6.18 \%$ lignin and $10.69 \%$ ash. Chopped SSS was dried in an oven at $70{ }^{\circ} \mathrm{C}$ to a constant weight. In total, 30 grams chopped sweet sorghum straw was suspended in $300 \mathrm{ml}$ of $3 \%$ sulfuric acid solution at $120{ }^{\circ} \mathrm{C}$, for 10 minutes. After pretreatment, the hydrolyzate was neutralized with $40 \% \mathrm{NaOH}$, centrifuged and filtered through $0.45 \mu \mathrm{m}$ filters before analyzing total reducing sugars with the DNS method and monomeric sugars (glucose, xylose, galactose, arabinose and mannose) by HPLC. The solid residue was collected by filtration and washed extensively with distilled water until a neutral $\mathrm{pH}$ was obtained. Acid-pretreated SSS was dried in an oven at $70{ }^{\circ} \mathrm{C}$ to a constant weight and used as a substrate for the saccharification experiment.

\subsection{Acid-Pretreated Sweet Sorghum Straw Saccharification}

A typical hydrolysis mixture consisted of $0.1 \mathrm{~g}$ acid pretreated SSS, $20 \mathrm{FPU} / \mathrm{g}$ dry substrate of cellulase from Celluclast 1.5, Novozyme or cellulase from Coriolus versicolor TD17 and $2.0 \mathrm{ml}$ sodium phosphate buffer (pH 6.0). Microbial contamination was prevented by adding $0.01 \mathrm{mg} / \mathrm{ml}$ sodium azide. The mixture was incubated at $50^{\circ} \mathrm{C}$ in a rotary shaker at $150 \mathrm{rpm}$ for 7 days. Samples were obtained from the reaction mixture at different time intervals. The samples were cooled, centrifuged for $10 \mathrm{~min}$ at $10,000 \mathrm{rpm}$, and the supernatant was used to analyze total reducing sugars by the DNS method and monomeric sugars by HPLC.

\subsection{Enzyme Assays}

Cellulase activity was assayed using a method that was described by Mandels and Weber (Mandels and Weber, 1969). The activity was estimated using $2 \% \mathrm{w} / \mathrm{v}$ carboxymethylcellulose in citrate buffer ( $50 \mathrm{mM}, \mathrm{pH} 4.8)$ as a substrate. The reaction mixture contained $1 \mathrm{ml}$ citrate buffer, $0.5 \mathrm{ml}$ substrate solution and $0.5 \mathrm{ml}$ diluted enzyme solution, and the reaction mixture was incubated at $50{ }^{\circ} \mathrm{C}$ for $30 \mathrm{~min}$. The liberated reducing sugars were estimated using the DNS method. One unit of enzyme activity was defined as the amount of enzyme that was required to yield one micromole reducing sugar and was expressed as glucose per min under the assay conditions.

\subsection{Monomeric Sugar Analyses}

High-performance liquid chromatography (HPLC) was used to determine monomeric sugar concentrations (xylose, glucose, galactose, arabinose and mannose) using an Aminex HPX-87P column (Bio-Rad, Richmond, USA) with a refractive index detector. The analysis was performed at $85{ }^{\circ} \mathrm{C}$ using Milli-Q water as the eluent with a flow rate of $0.6 \mathrm{ml} / \mathrm{min}$. Sample peak areas were identified and quantified by comparing with the retention times of known analytical standards (glucose, xylose, galactose, arabinose and mannose). 


\subsection{Statistical Analyses}

All of the experiments were performed in triplicate and the related data were expressed as average values. Enzymatic saccharification experimental data were analyzed using SPSS software with one-way analysis of variance (ANOVA) followed by Tukey's multiple range method test to compare means. Differences in means were judged to be significant when $p$ values for the null hypothesis were 0.05 or less.

\subsection{Response Surface Methodology (RSM)}

A factorial, central composite design (CCD) for four factors with replicates at the center point and star points were used in this investigation. Saccharification condition variables were 1-7\% substrate concentration, $15-35$ FPU/g substrate cellulase concentration, temperature $30-70{ }^{\circ} \mathrm{C}$ and $\mathrm{pH} 3-7$. Each variable at five coded levels (- $\alpha$, $-1,0,+1,+\alpha)$ was assessed using statistical analysis and RSM as demonstrated in Table 2 . The actual variable levels for the CCD experiments were selected based on using the initial levels as the center points. A total of thirty experimental trials, including sixteen for factorial design, eight for axial points (two for each variable) and six for replication of the central points were performed. The Design-Expert 8.0 statistical software package (Stat-Ease, Inc., Minneapolis, USA) was used for experimental data regression analysis and to plot the response surface.

Table 2. Variables and their levels for central composite experimental design

\begin{tabular}{cccccccc}
\hline \multirow{2}{*}{ Variables } & Units & \multirow{2}{*}{ Symbol } & \multicolumn{5}{c}{ Code levels } \\
\cline { 4 - 8 } & & & -2 & -1 & 0 & 1 & 2 \\
\hline Substrate & $\% \mathrm{w} / \mathrm{v}$ & $\mathrm{A}$ & $1 \%$ & $2.5 \%$ & $4 \%$ & $5.5 \%$ & $7 \%$ \\
Cellulase & $\mathrm{FPU} / \mathrm{g}$ dry substrate & $\mathrm{B}$ & 15 & 20 & 25 & 30 & 35 \\
Temperature & ${ }^{\circ} \mathrm{C}$ & $\mathrm{C}$ & 30 & 40 & 50 & 60 & 70 \\
$\mathrm{pH}$ & - & $\mathrm{D}$ & 3 & 4 & 5 & 6 & 7 \\
\hline
\end{tabular}

\section{Results}

\subsection{Effect of Carbon Sources on Cellulase Production}

The effect of carbon sources carboxymethylcellulose, cellobiose, avicel and $\alpha$-cellulose on cellulase production was investigated at different cultivation times.

The experimental results demonstrated in Figure 1, indicated that cellobiose was the best carbon source followed by carboxymethylcellulose whereas avicel and $\alpha$-cellulose had no significant effect on cellulase production. The highest cellulase activity $(0.829 \mathrm{U} / \mathrm{ml}$ after 9 days of cultivation) was obtained when cellobiose was used as the sole carbon source. Carboxymethylcellulose, avicel and $\alpha$-cellulose cellulase activities were $0.446 \mathrm{U} / \mathrm{ml}, 0.276$ $\mathrm{U} / \mathrm{ml}$ and $0.239 \mathrm{U} / \mathrm{ml}$ after 9 days cultivation time, respectively. In the presence of either avicel or $\alpha$-cellulose, cell dry weight was significantly increased, in contrast with cellulase activity. Including avicel and $\alpha$-cellulose in the media supported high $C$. versicolor TD17 cell growth but resulted in minimal cellulase production. The obvious high $C$. versicolor TD17 cell growth in the presence of avicel or $\alpha$-cellulose as a carbon source was four times higher compared with using carboxymethylcellulose and cellobiose as carbon sources. This might be an error from the cell growth measurement method. These values included residual avicel or $\alpha$-cellulose because we used cell dry weight to represent cell growth.

The cellulase activity time course study using cellobiose as a carbon source revealed a significant increase in enzyme production with cultivation time. Cellulase activity was $0.621 \mathrm{U} / \mathrm{ml}$ and $0.829 \mathrm{U} / \mathrm{ml}$ after 2 and 9 days of cultivation time, respectively, which was because of rapid cellulose hydrolysis in the media. Further increases in fermentation (after 9 days) resulted in decreased cellulase activity. 




Figure 1. Effect of carbon sources on cellulase production from Coriolus versicolor TD17

Cells were cultivated for 11 days in $250 \mathrm{ml}$ erlemeyer flasks with an initial various carbon source of $20 \mathrm{~g} / \mathrm{l}$.

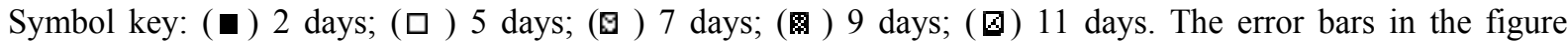
indicated the standard deviation (SD) among three parallel replicates.

The analyses of variance for all of the data using SPSS software (data not shown) indicated that the means of various carbon sources used for cellulase production from C. versicolor TD17 were statistically different with a $95 \%$ confidence interval with Tukey's test result at $\alpha=0.05$. A maximal cellulase activity of $0.7064 \mathrm{U} / \mathrm{ml}$ was obtained with $20 \mathrm{~g} / 1$ cellobiose followed by carboxymethylcellulose, avicel and $\alpha$-cellulose, respectively. This result may be attributable to cellulase enzyme induction because cellulose is a universal inducer of cellulase synthesis (Paul \& Varma, 1993). Considering the time course of cellulase production, the highest cellulase amount was obtained at the $9^{\text {th }}$ day of cultivation. Increasing cultivation time from 2-9 days exhibited a significant increase cellulase production, whereas increasing cultivation time from 5-9 days had no significant on cellulase production, but cellulase production was significantly decreased when cultivation time was extended longer than 9 days. This observation was in close agreement with the results of SzabÓ et al., who demonstrated optimal cellulase production to be $129 \mathrm{mg}$ cellulase/g dry substrate from Phanerochaete chrysosporium when using $20 \mathrm{~g} / \mathrm{l}$ cellobiose as a carbon source (SzabÓ et al., 1996).

\subsection{Effect of Nitrogen Sources on Cellulase Production}

Cultivation with various nitrogen sources such as ammonium sulfate, ammonium nitrate, peptone, yeast extract and urea were substituted for control nitrogen sources (ammonium sulfate, peptone and urea) in the basal media. The experimental results demonstrated in Figure 2, indicated that ammonium nitrate was the best nitrogen source followed by ammonium sulfate, control media, urea, peptone and yeast extract.

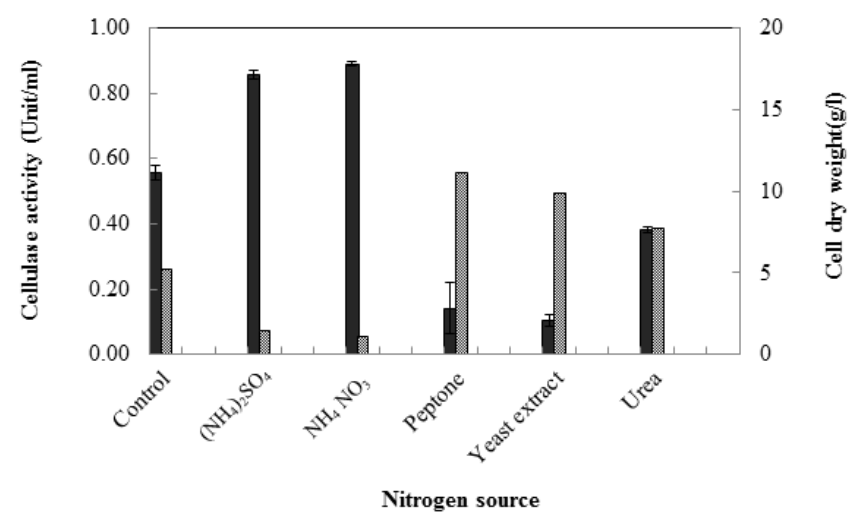

Figure 2. Effect of nitrogen sources on cellulase production from Coriolus versicolor TD17

Cells were cultivated for 5 days in $250 \mathrm{ml}$ erlemeyer flasks with an initial various nitrogen source of $4 \mathrm{~g} / \mathrm{l}$. Symbol key: ( $)$ cellulase activity $(\mathrm{U} / \mathrm{ml})$; ( $⿴ 囗$ ) cell dry weight $(\mathrm{g} / \mathrm{l})$. The error bars in the figure indicated the standard deviation (SD) among three parallel replicates. *Control (ammonium sulfate, peptone and urea). 
The analyses of variance for all of the data using SPSS software (data not shown) demonstrated that various nitrogen sources that are used as a substrate for cellulase production from C. versicolor TD17 were statistically different with a $95 \%$ confidence interval followed by Tukey's test at $\alpha=0.05$. Maximum cellulase activity of $0.888 \mathrm{U} / \mathrm{ml}$ was obtained with $4 \mathrm{~g} / \mathrm{l}$ ammonium nitrate as the sole nitrogen source followed by ammonium sulfate, control, urea, peptone and yeast extract, respectively. However, with ammonium nitrate or ammonium sulfate as substrate, there were no significant effects on cellulase production. Considering the cost of the nitrogen source, using ammonium sulfate will improve the economic cost of cellulase production from C. versicolor TD17. Adding an organic nitrogen source, such as peptone or yeast extract resulted in increased cell growth but gave a small amount of enzyme production. More literature data indicated that inorganic nitrogen sources should be used for economic aspects. From our results, ammonium sulfate itself could act as a suitable nitrogen source for cellulase production. Furthermore, the optimal ammonium sulfate concentration was investigated. These results demonstrated that $2 \mathrm{~g} / \mathrm{l}$ ammonium sulfate yielded maximum cellulase activity of $0.606 \mathrm{U} / \mathrm{ml} 5$ days after cultivation (data not shown). Several adjustments in combination with nitrogen sources were also investigated for greater cellulase production (Liu \& Yang, 2007).

\subsection{Effect of Combined Nitrogen Sources on Cellulase Production}

The influence of each nitrogen source on cellulase production and cell growth from C.versicolor TD17 was investigated using media in which only a single nitrogen source was taken from the production media compared with using only ammonium sulfate as a nitrogen source and control media that consisted of three nitrogen sources. Experimental results were shown in Figure 3, which indicated that the culture media that consisted of only ammonium sulfate as a nitrogen source exhibited the maximum cellulase activity of $0.579 \mathrm{U} / \mathrm{ml}$ higher than the control media. Culture using media without urea demonstrated lower cellulase activity than the control media, whereas the dry cell weight was similar to the control. Cultivation using the media without peptone demonstrated high cell growth but produced less cellulase than the control media. Therefore, urea and peptone were necessary for cell growth. These results indicated that supplementing with more than one nitrogen source affected cell growth.

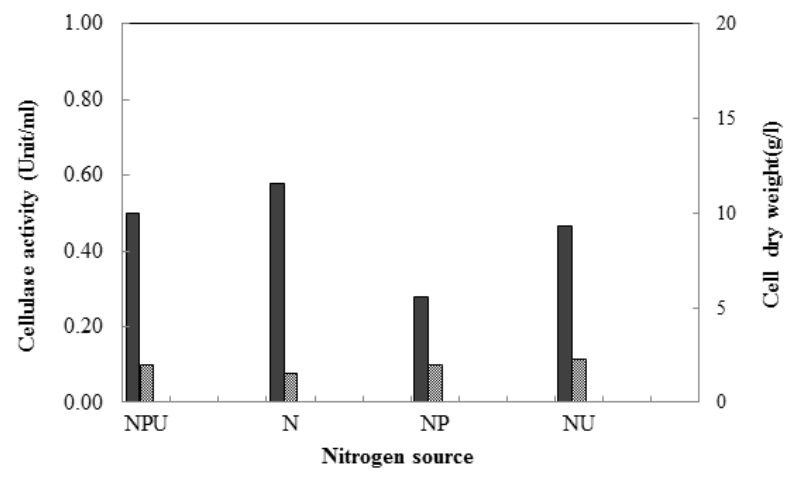

Figure 3. Effect of combined nitrogen sources on cell growth and cellulase production from Coriolus versicolor TD17

Cells were cultivated for 5 days in $250 \mathrm{ml}$ erlemeyer flasks with combined nitrogen sources. Symbol key: cellulase activity $(\mathrm{U} / \mathrm{ml}) ;\left(\right.$ ) cell dry weight $(\mathrm{g} / \mathrm{l}) .{ }^{*}$ Control (NPU = ammonium sulfate, peptone and urea).

The analyses of variance was performed for all of the data using SPSS software (data not shown) and demonstrated that combined nitrogen sources when used as substrates for cellulase production from C.versicolor TD17 were statistically different with a 95\% confidence interval and Tukey's test was $\alpha=0.05$. Maximum cellulase activity $(0.579 \mathrm{U} / \mathrm{ml})$ was obtained when $2 \mathrm{~g} / \mathrm{l}$ ammonium sulfate was used as a sole nitrogen source followed by a control nitrogen source (NPU), ammonium sulfate with urea (NU) and ammonium sulfate with peptone (NP). There were no significant differences in cellulase production when using control media or ammonium sulfate with urea (NU) serving as a nitrogen source. The statistical analysis results clearly demonstrated that supplementation with $2 \mathrm{~g} / \mathrm{l}$ ammonium sulfate was optimal for cellulase production but neither urea nor peptone had any effect on cellulose production. However, we used $2 \mathrm{~g} / \mathrm{l}$ ammonium sulfate supplement with $0.3 \mathrm{~g} / 1$ urea, which had a synergistic effect on cell growth. These results were in accordance with those that were reported by Ikeda (Ikeda et al., 2007). Various cultivation media and cellulase production conditions from 
different microorganism species sources were also summarized in Table 3.

Table 3. Comparison of cellulase production by different microorganism species and substrates

\begin{tabular}{|c|c|c|c|c|c|c|c|}
\hline $\begin{array}{l}\text { Microorganism } \\
\text { Species }\end{array}$ & Carbon Sources & Nitrogen Sources & $\mathrm{pH}$ & $\begin{array}{l}\text { Temp. } \\
\left({ }^{\circ} \mathrm{C}\right)\end{array}$ & $\begin{array}{l}\text { Cultivation } \\
\text { Time } \\
\text { (Days) }\end{array}$ & $\begin{array}{l}\text { Cellulase } \\
\text { Activity } \\
(\mathrm{U} / \mathrm{ml})\end{array}$ & References \\
\hline $\begin{array}{l}\text { Trichoderma } \\
\text { reesei Rut C-30 }\end{array}$ & $\begin{array}{l}25 \mathrm{~g} / 1 \text { cellulose, } 25 \\
\mathrm{~g} / 1 \text { sugar beet pulp }\end{array}$ & $\begin{array}{c}0.3 \mathrm{~g} / 1 \text { urea, } 1.4 \mathrm{~g} / 1 \\
\left(\mathrm{NH}_{4}\right)_{2} \mathrm{SO}_{4}, 0.25 \mathrm{~g} / 1 \\
\text { yeast extract }\end{array}$ & 5.0 & 28 & 4 & 0.450 & $\begin{array}{l}\text { (Olsson et al., } \\
2003 \text { ) }\end{array}$ \\
\hline $\begin{array}{l}\text { Aspergillus } \\
\text { Niger }\end{array}$ & $1.0 \%$ cellulose & $3 \mathrm{~g} / 1$ urea & 5.0 & 28 & 7 & 0.824 & $\begin{array}{l}\text { (Narasimha et } \\
\text { al., 2006) }\end{array}$ \\
\hline $\begin{array}{l}\text { Streptomyces Sp. } \\
\text { (Strain J2) }\end{array}$ & $0.2 \%$ glucose & $0.2 \% \mathrm{NH}_{4} \mathrm{Cl}$ & 7.0 & 30 & 3 & 0.432 & $\begin{array}{l}\text { (Jaradat et al., } \\
\text { 2008) }\end{array}$ \\
\hline $\begin{array}{l}\text { Aspergillus } \\
\text { Niger }\end{array}$ & $9.6 \%$ sawdust & $\begin{array}{c}0.3 \mathrm{~g} / 1 \text { urea, } 1.4 \mathrm{~g} / 1 \\
\left(\mathrm{NH}_{4}\right)_{2} \mathrm{SO}_{4}, 1.0 \mathrm{~g} / 1 \\
\text { peptone }\end{array}$ & $4.0-4.5$ & 28 & 4 & 0.181 & $\begin{array}{l}\text { (Acharya et } \\
\text { al., 2008) }\end{array}$ \\
\hline $\begin{array}{l}\text { Bacillus } \\
\text { alcalophilus S39 }\end{array}$ & $1 \% \mathrm{CMC}$ & $0.7 \%$ yeast extract & 7.0 & 30 & 3 & 2.070 & $\begin{array}{l}\text { (Taleb et al., } \\
\text { 2009) }\end{array}$ \\
\hline $\begin{array}{l}\text { Coprinellus } \\
\text { disseminates }\end{array}$ & $20 \mathrm{~g} / 1$ glucose & $1 \mathrm{~g} / 1$ yeast extract & 6.4 & 37 & 7 & 0.925 & $\begin{array}{l}\text { (Singh et al., } \\
2009 \text { ) }\end{array}$ \\
\hline $\begin{array}{l}\text { Agaricus } \\
\text { arvensis }\end{array}$ & $20 \mathrm{~g} / 1$ rice straw & $5 \mathrm{~g} / 1$ tryptone & - & - & 12 & 2.600 & $\begin{array}{l}\text { (Jeya et al., } \\
2010)\end{array}$ \\
\hline $\begin{array}{l}\text { Coriolus } \\
\text { versicolor TD17 }\end{array}$ & $20 \mathrm{~g} / 1$ cellobiose & $\begin{array}{c}2 \mathrm{~g} / 1\left(\mathrm{NH}_{4}\right)_{2} \mathrm{SO}_{4}, 0.3 \mathrm{~g} / \mathrm{l} \\
\text { urea }\end{array}$ & 5 & 30 & 5 & 0.897 & This work \\
\hline
\end{tabular}

3.4 Optimization of Cellulase Saccharification Conditions From C. versicolor TD17 Using Response Surface Methodology

Experiments were performed using saccharification conditions that were obtained by central composite design of four independent variables: substrate concentration, cellulase concentration produced by C. versicolor TD17, temperature and $\mathrm{pH}$. Experimental values were expressed as the total reducing sugars and glucose concentration obtained after $72 \mathrm{~h}$ saccharification. Thirty experiments were performed in triplicate corresponding to each combination and were summarized in Table 4. 
Table 4. Central composite design (CCD) four factor variables at five code levels by cellulase enzyme from Coriolus versicolor TD17

\begin{tabular}{|c|c|c|c|c|c|c|}
\hline Sample No. & $\begin{array}{c}\text { Substrate } \\
(\% \mathrm{w} / \mathrm{v})\end{array}$ & $\begin{array}{c}\text { Enzyme } \\
\text { (FPU/g DS) }\end{array}$ & Temp. $\left({ }^{\circ} \mathrm{C}\right)$ & $\mathrm{pH}$ & $\begin{array}{l}\text { Actual glucose } \\
\text { (g/g DS) }\end{array}$ & $\begin{array}{l}\text { Predicted glucose } \\
\text { (g/g DS) }\end{array}$ \\
\hline 1 & 5.5 & 20 & 40 & 6 & 0.058 & 0.023 \\
\hline 2 & 4.0 & 25 & 50 & 5 & 0.103 & 0.100 \\
\hline 3 & 2.5 & 30 & 60 & 4 & 0.069 & 0.115 \\
\hline 4 & 5.5 & 30 & 60 & 6 & 0.017 & 0.023 \\
\hline 5 & 4.0 & 25 & 50 & 5 & 0.089 & 0.100 \\
\hline 6 & 5.5 & 30 & 40 & 4 & 0.139 & 0.107 \\
\hline 7 & 2.5 & 20 & 40 & 6 & 0.150 & 0.148 \\
\hline 8 & 4.0 & 25 & 50 & 5 & 0.113 & 0.100 \\
\hline 9 & 5.5 & 30 & 60 & 4 & 0.059 & 0.040 \\
\hline 10 & 2.5 & 20 & 60 & 4 & 0.099 & 0.120 \\
\hline 11 & 2.5 & 20 & 40 & 4 & 0.233 & 0.239 \\
\hline 12 & 5.5 & 20 & 60 & 6 & 0.025 & 0.002 \\
\hline 13 & 2.5 & 20 & 60 & 6 & 0.004 & 0.047 \\
\hline 14 & 5.5 & 20 & 40 & 4 & 0.100 & 0.076 \\
\hline 15 & 5.5 & 20 & 60 & 4 & 0.036 & 0.037 \\
\hline 16 & 2.5 & 30 & 60 & 6 & 0.058 & 0.060 \\
\hline 17 & 2.5 & 30 & 40 & 6 & 0.178 & 0.189 \\
\hline 18 & 5.5 & 30 & 40 & 6 & 0.114 & 0.072 \\
\hline 19 & 2.5 & 30 & 40 & 4 & 0.260 & 0.262 \\
\hline 20 & 4.0 & 25 & 50 & 5 & 0.119 & 0.100 \\
\hline 21 & 4.0 & 25 & 50 & 5 & 0.115 & 0.100 \\
\hline 22 & 4.0 & 15 & 50 & 5 & 0.100 & 0.064 \\
\hline 23 & 4.0 & 25 & 70 & 5 & 0.042 & 0.040 \\
\hline 24 & 4.0 & 25 & 50 & 7 & 0.000 & 0.026 \\
\hline 25 & 4.0 & 25 & 50 & 3 & 0.122 & 0.082 \\
\hline 26 & 1.0 & 25 & 50 & 5 & 0.440 & 0.332 \\
\hline 27 & 4.0 & 25 & 30 & 5 & 0.114 & 0.128 \\
\hline 28 & 4.0 & 35 & 50 & 5 & 0.136 & 0.108 \\
\hline 29 & 7.0 & 25 & 50 & 5 & 0.087 & 0.132 \\
\hline 30 & 4.0 & 25 & 50 & 5 & 0.132 & 0.100 \\
\hline
\end{tabular}

Applying the RSM yielded the regression equation, which had an empirical relationship between the glucose concentration and the test variables in coded units. The statistical significance of the model equation (Equation 1) was assessed using the $F$-test, and the analysis of variance (ANOVA) for the response surface quadratic model was shown in Table 5. 
Table 5. Analysis of variance (ANOVA) for the response surface quadratic model

\begin{tabular}{ccccc}
\hline & & & \\
Source & Sum of Squares & Mean Square & F-value & p-value Prob $>$ F \\
& & & & \\
\hline Model & 0.183 & $1.31 \times 10^{-2}$ & 6.75 & 0.0005 \\
A-Substrate (\%w/v) & $6.09 \times 10^{-2}$ & $6.09 \times 10^{-2}$ & 31.36 & $<0.0001$ \\
B-Enzyme (FPU/g DS) & $2.79 \times 10^{-3}$ & $2.79 \times 10^{-3}$ & 1.44 & 0.2501 \\
C-temperature $\left({ }^{\circ} \mathrm{C}\right)$ & $4.26 \times 10^{-2}$ & $4.26 \times 10^{-2}$ & 21.94 & 0.0004 \\
D-pH & $1.69 \times 10^{-2}$ & $1.69 \times 10^{-2}$ & 8.72 & 0.0105 \\
AB & $5.84 \times 10^{-5}$ & $5.84 \times 10^{-5}$ & 0.03 & 0.8647 \\
AC & $6.33 \times 10^{-3}$ & $6.33 \times 10^{-3}$ & 3.26 & 0.0925 \\
AD & $1.44 \times 10^{-3}$ & $1.44 \times 10^{-3}$ & 0.74 & 0.4037 \\
BC & $7.73 \times 10^{-4}$ & $7.73 \times 10^{-4}$ & 0.40 & 0.5381 \\
BD & $3.23 \times 10^{-4}$ & $3.23 \times 10^{-4}$ & 0.17 & 0.6894 \\
CD & $3.21 \times 10^{-4}$ & $3.21 \times 10^{-4}$ & 0.17 & 0.6903 \\
$\mathrm{~A}^{2}$ & $2.97 \times 10^{-2}$ & $2.97 \times 10^{-2}$ & 15.29 & 0.0016 \\
$\mathrm{~B}^{2}$ & $3.47 \times 10^{-4}$ & $3.47 \times 10^{-4}$ & 0.18 & 0.6788 \\
$\mathrm{C}^{2}$ & $5.03 \times 10^{-3}$ & $5.03 \times 10^{-3}$ & 2.59 & 0.1298 \\
$\mathrm{D}^{2}$ & $8.58 \times 10^{-3}$ & $8.58 \times 10^{-3}$ & 4.42 & 0.0541 \\
\hline & & &
\end{tabular}

Form the model, $F$ value was 12.83 and probability values ( $P$-values $)>F$ values or $\alpha<0.0001$, which implied that the model was significant $(P<0.05)$. This model with a very low probability value demonstrated high significance for the regression model. These data indicated that the model was statistically significant with a $95 \%$ confidence interval, a coefficient of determination $\left(\mathrm{R}^{2}\right)$ of 0.8709 , the coefficient of the varation $(\mathrm{CV})$ of $39.915 \%$, lack of fit of 0.0090 (significance) and pure error of 0.00069 . The model is stronger and the predicted response is better as the $\mathrm{R}^{2}$ value becomes closer to 1.0. However, Ferreira et al. reported that $\mathrm{R}^{2}$ value $>0.75$ indicate the model's tendency (Ferreira et al., 2009). Therefore, the model was applicable for predicting saccharification conditions in this study. Reaction variable interaction was presented using ANOVA. These data demonstrated that individual variables on saccharification conditions were significantly $(P<0.05)$ affected by substrate concentration, enzyme concentration, temperature and $\mathrm{pH}$. The effect of substrate concentration was significant $(P<0.0001)$, while the effect of enzyme concentration was not significant $(P=0.2501)$. Temperature and $\mathrm{pH}$ were the most significant variables because of very low probability values $(P=0.0004$ and 0.0105$)$

The RSM application yielded the following overall second-degree quadratic polynomial equation for saccharification, which is given by the following equation:

$\mathrm{Y}=0.1165-0.0504 \mathrm{~A}+0.0108 \mathrm{~B}-0.0421 \mathrm{C}-0.0267 \mathrm{D}+1.9109 \times 10^{-3} \mathrm{AB}+0.0199 \mathrm{AC}+9.4834 \times 10^{-3} \mathrm{AD}-6.9507 \times 10^{-3} \mathrm{BC}$ $+4.4947 \times 10^{-3} \mathrm{BD}+4.4810 \times 10^{-3} \mathrm{CD}+0.0329 \mathrm{~A}^{2}-3.557 \times 10^{-3} \mathrm{~B}^{2}-0.0135 \mathrm{C}^{2}-0.0177 \mathrm{D}^{2}$

Where $\mathrm{Y}$ denotes the glucose concentration ( $\mathrm{g}$ glucose/g dry substrate), A is the substrate concentration (\%w/v), $\mathrm{B}$ is the enzyme concentration (FPU/g dry substrate), $\mathrm{C}$ is the temperature $\left({ }^{\circ} \mathrm{C}\right)$, and $\mathrm{D}$ is the $\mathrm{pH}$. Model accuracy was assessed by plotting between the actual and the predicted glucose concentrations. The normality assumption was satisfactory because normal residuals fell along a straight line as shown in Figure 4. 


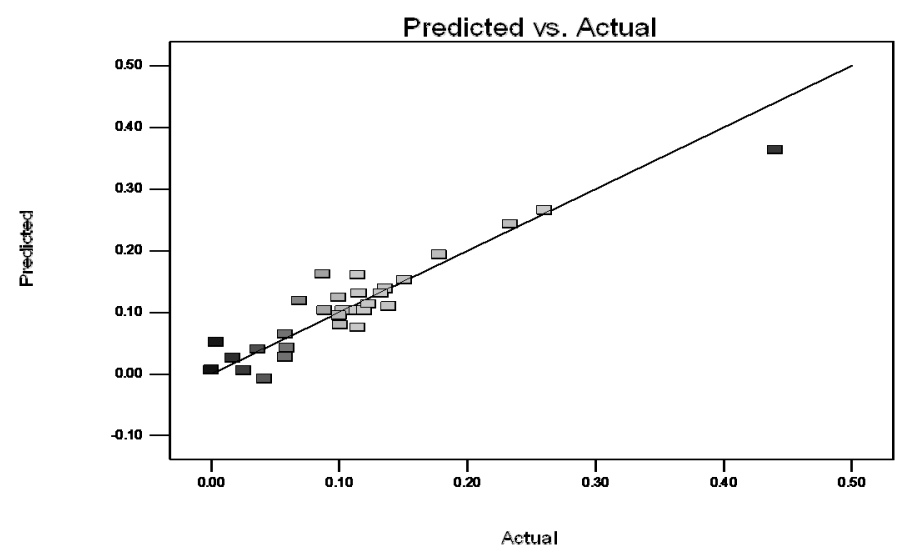

Figure 4. Correlation between the actual and the predicted glucose concentration that was liberated from acid-pretreated sweet sorghum straw using cellulase enzyme from Coriolus versicolor TD17

The response was plotted on the Z-axis to obtain 3D response surface plots (g glucose/g dry substrate) against any two variables while keeping the other variable constant at its ' 0 ' level.

A

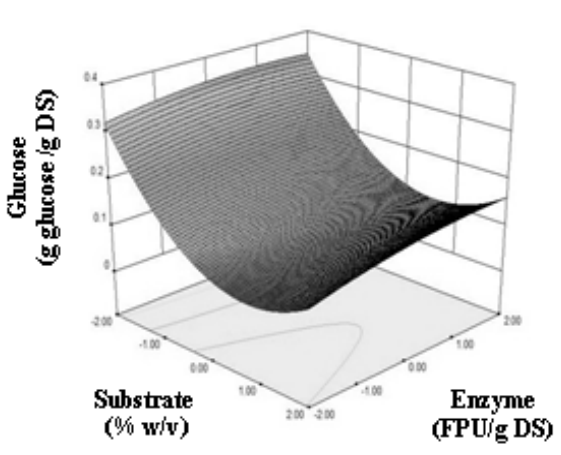

$\mathrm{C}$

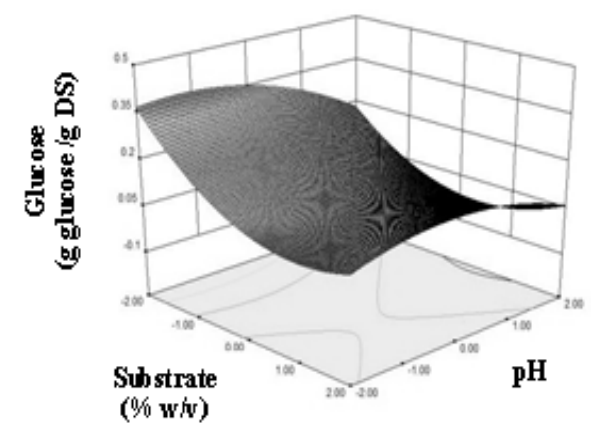

B

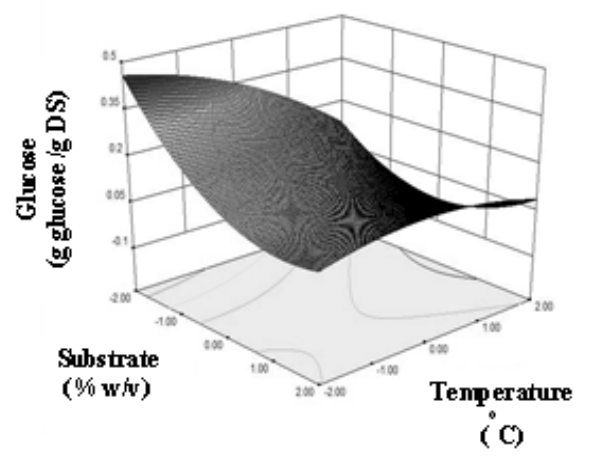

D

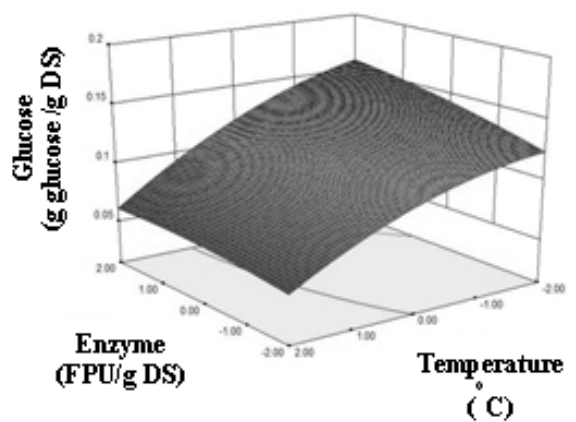





Figure 5. Response surface plots demonstrating interactions among variables in converting the acid pretreated SSS to glucose

(A) interaction between substrate and enzyme concentrations; (B) interaction between substrate concentration and temperature; (C) interaction between substrate concentration and $\mathrm{pH}$; (D) interaction between enzyme concentration and temperature; (E) interaction between enzyme concentration and $\mathrm{pH}$; $(\mathrm{F})$ interaction between temperature and $\mathrm{pH}$. Perturbation graph demonstrating the effect of each variable on saccharification, while keeping other variables at respective ' 0 ' levels. A - substrate concentration $(\% \mathrm{w} / \mathrm{v})$; B - enzyme concentration (FPU/g dry substrate); $\mathrm{C}-$ temperature $\left({ }^{\circ} \mathrm{C}\right) ; \mathrm{D}-\mathrm{pH}$. Axis $\mathrm{X}$ and $\mathrm{Y}$ denoted vaiables (substrate, enzyme, temperature and $\mathrm{pH}$ ); axis $\mathrm{Z}$ denoted saccharification yield (glucose).

Isoresponse contour and surface plots for optimal saccharification condition were demonstrated in Figure 5. From Figure 5A, substrate concentration in the range 1-7\% w/v had a negative effect, which resulted in significantly decreased glucose concentrations. Increasing the enzyme concentration from 15 to $35 \mathrm{FPU} / \mathrm{g}$ dry substrate did not further increase glucose concentration. The optimal substrate concentration was approximately $1.0-2.5 \% \mathrm{w} / \mathrm{v}$ with temperature between 30 and $40{ }^{\circ} \mathrm{C}$ and $\mathrm{pH}$ between 3 and 5 (Figure 5B and Figure 5C). The optimal glucose yield was obtained at low temperatures $\left(30^{\circ} \mathrm{C}\right)$ but gradually decreased at temperatures over $50{ }^{\circ} \mathrm{C}$ (Figure 5D). Increasing enzyme concentrations (15-35 FPU/g dry substrate) produced no significant differences in glucose yield. The optimal enzyme concentration was approximately $15-35 \mathrm{FPU} / \mathrm{g}$ substrate with a $\mathrm{pH}$ between 3 and 5 (Figure 5E. The optimal temperature and $\mathrm{pH}$ were between 30 and $50{ }^{\circ} \mathrm{C}$ and 3 and 5 (Figure 5F), respectively. These data demonstrated that individual variables on saccharification conditions were significantly $(P<0.05)$ affected by substrate concentration, enzyme concentration, temperature and $\mathrm{pH}$. The effect of substrate concentration was significant $(P<0.0001)$, while the effect of enzyme concentration was not significant $(P=0.2501)$. Temperature and $\mathrm{pH}$ were the most significant variables because of very low probability values $(P=0.0004$ and 0.0105$)$.

In summary, response surface methodology was successfully applied to optimize enzymatic saccharification conditions of the acid-pretreated SSS by applying cellulase from a white rot fungus, Coriolus versicolor TD17. Optimal saccharification conditions were obtained using $1 \%$ of the acid pretreated SSS, $25 \mathrm{FPU} / \mathrm{g}$ dry substrate in house cellulase, $\mathrm{pH} 5$ and a temperature of $50^{\circ} \mathrm{C}$, which provided a maximum yield of $0.440 \mathrm{~g}$ glucose/g dry substrate (Run No.26 in Table 4) at $72 \mathrm{~h}$ incubation time. Optimal saccharification conditions of several commercial cellulase and substrate concentrations were in the range 15-35 FPU/g dry substrate and 1.0-5.0\% w/v, respectively (Cara et al., 2008; Jeya et al., 2010). 
Table 6. Summary of the combined yield of monosugars that were liberated from sweet sorghum straw acid pretreatment (stage 1) and enzymatic saccharification of the pretreated sweet sorghum straw using cellulase from Coriolus versicolor TD17 (stage 2)

\begin{tabular}{ccccc}
\hline \multirow{2}{*}{ Conditions } & \multicolumn{4}{c}{ Yield avg $(\mathrm{g}$ monosugar $/ \mathrm{g}$ dry substrate $)$} \\
\cline { 2 - 5 } & Glucose & Xyl & Gal, Man, Ara & Total sugars \\
\hline Stage 1 & $0.234 \pm 0.079$ & $0.208 \pm 0.073$ & $0.235 \pm 0.164$ & $0.676 \pm 0.230$ \\
Stage 2 & $0.440 \pm 0.001$ & 0 & 0 & $0.440 \pm 0.001$ \\
Stage1+Stage2 & $0.674 \pm 0.080$ & $0.208 \pm 0.073$ & $0.235 \pm 0.164$ & $1.116 \pm 0.231$ \\
\hline
\end{tabular}

Overall SSS hydrolysis including acid pretreatment and enzymatic saccharification was shown in Table 6, maximum glucose yield was $0.674 \mathrm{~g} / \mathrm{g}$ dry substrate, the maximum xylose yield was $0.208 \mathrm{~g} / \mathrm{g}$ dry substrate and other monosugars (galactose, mannose and arabinose) were $0.235 \mathrm{~g} / \mathrm{g}$ dry substrate. Optimal conditions for lignocellulosic material hydrolysis by cellulolytic enzymes gave the indicated values for "maximum fermentative sugar concentration" that are summarized in Table 7.

Table 7. Summary of the optimal conditions for cellulase activity to saccharify lignocellulosic materials

\begin{tabular}{|c|c|c|c|c|c|c|}
\hline Source of cellulase & $\begin{array}{l}\text { Enzyme } \\
\text { concentration } \\
\text { (FPU/g DS) }\end{array}$ & $\begin{array}{l}\text { Substrate } \\
\text { Concentration }(\mathrm{g} / \mathrm{g} \\
\text { DS) }\end{array}$ & $\begin{array}{l}\text { Temperature } \\
\left({ }^{\circ} \mathrm{C}\right)\end{array}$ & $\mathrm{pH}$ & $\begin{array}{l}\text { Reducing sugars } \\
\text { (g/g-DS) }\end{array}$ & References \\
\hline Trametes hirsute & $30 \mathrm{FPU} / \mathrm{g}$-substrate & $2.25 \%$ rice straw & $25-35$ & 5 & $0.685 \mathrm{~g} \mathrm{RS} / \mathrm{g}$ DS & $\begin{array}{l}\text { (Jeya et al., } \\
2010)\end{array}$ \\
\hline Agaricus arvensis & $65 \mathrm{FPU} / \mathrm{g}$-substrate & $10 \%$ poplar & 37 & 5 & $0.293 \mathrm{~g} \mathrm{RS} / \mathrm{g}$ DS & $\begin{array}{l}\text { (Jeya et al., } \\
2010)\end{array}$ \\
\hline \multirow{2}{*}{$\begin{array}{l}\text { Novozyme NS50013 } \\
\text { (Cellulase complex) }\end{array}$} & $60 \mathrm{FPU} / \mathrm{g}$ substrate & $\begin{array}{l}0.40 \% \text { pretreated } \\
\text { rock-rose }\end{array}$ & 50 & 4.86 & $0.313 \mathrm{~g} \mathrm{RS} / \mathrm{g}$ DS & $\begin{array}{l}\text { (Ferreira et al., } \\
\text { 2009) }\end{array}$ \\
\hline & $60 \mathrm{FPU} / \mathrm{g}$ substrate & $\begin{array}{l}0.27 \% \text { pretreated } \\
\text { broom }\end{array}$ & 50 & 4.5 & $0.448 \mathrm{~g}$ glu. $/ \mathrm{g}$ DS & $\begin{array}{l}\text { (Ferreira et al., } \\
\text { 2009) }\end{array}$ \\
\hline $\begin{array}{l}\text { Commercial cellulase } \\
\text { from Aspergillus niger }\end{array}$ & $0.16(\mathrm{v} / \mathrm{v})$ & $50 \%$ food waste & 46.3 & 5.2 & $0.117 \mathrm{~g} \mathrm{RS} / \mathrm{g}$ DS & $\begin{array}{l}\text { (Kim et al., } \\
2008)\end{array}$ \\
\hline $\begin{array}{l}\text { Commercial cellulase } \\
\text { from Novozymes }\end{array}$ & $15 \mathrm{FPU} / \mathrm{g}$ substrate & $\begin{array}{l}5 \% \text { olive tree } \\
\text { biomass }\end{array}$ & 50 & 4.8 & $0.363 \mathrm{~g}$ glu. $/ \mathrm{s}$ DS & $\begin{array}{l}\text { (Cara et al., } \\
\text { 2008) }\end{array}$ \\
\hline $\begin{array}{l}\text { Coriolus versicolor } \\
\text { TD17 }\end{array}$ & $\begin{array}{l}25 \quad \mathrm{FPU} / \mathrm{g} \text { dry } \\
\text { substrate }\end{array}$ & $\begin{array}{l}1 \% \mathrm{w} / \mathrm{v} \text { sweet } \\
\text { sorghum straw }\end{array}$ & 50 & 5 & $\begin{array}{l}0.440 \mathrm{~g} \text { glu } / \mathrm{g} \text { dry } \\
\text { substrate }\end{array}$ & This work \\
\hline
\end{tabular}

\section{Conclusions}

Optimal cellulase production from C.versicolor TD17 was obtained using $20 \mathrm{~g} / 1$ cellobiose, $2 \mathrm{~g} / 1$ ammonium sulfate and supplemented with $0.3 \mathrm{~g} / 1$ urea. Maximum activity $(0.897 \mathrm{U} / \mathrm{ml})$ was obtained after 5 th day of cultivation. From RSM study, optimal saccharification conditions of cellulase from C.versicolor TD17 were 1\% 
w/v acid-pretreated SSS, $25 \mathrm{FPU} / \mathrm{g}$ dry substrate, $50^{\circ} \mathrm{C}$ and $\mathrm{pH}$ 5. Similarly, optimal saccharification conditions by commercial cellulase from $T$. reesei were $2.5 \% \mathrm{w} / \mathrm{v}$ acid-pretreated SSS, $15 \mathrm{FPU} / \mathrm{g}$ dry substrate, $40{ }^{\circ} \mathrm{C}$ and $\mathrm{pH}$ 4. The maximum yield of 0.440 and $0.558 \mathrm{~g}$ glucose $/ \mathrm{g}$ dry substrate (data not shown) were obtained after 72 $\mathrm{h}$, respectively. SSS has a potential as an alternative renewable resource for liberating fermentative sugars.

\section{References}

Acharya, P. B., Acharya, D. K., \& Modi, H. A. (2008). Optimization for cellulose production by Aspergillus niger using saw dust as substrate. African Journal of Biotechnology, 7, 4147-4152.

Cara, C. R. E., Oliva, J. M., Sa'ez, F., \& Castro, E. (2008). Conversion of olive tree biomass into fermentable sugars by dilute acid pretreatment and enzymatic saccharification. Bioresource Technology, 99, 869-1876. http://dx.doi.org/10.1016/j.biortech.2007.03.037

Ferreira, S., Duartea, A. P., Ribeirob, M. H. L., Queiroza, J. A., \& Domingues, F. C. (2009). Response surface optimization of enzymatic hydrolysis of Cistus ladanifer and Cytisus striatus for bioethanol production. Biochemical Engineering Journal, 45, 192-200. http://dx.doi.org/10.1016/j.bej.2009.03.012

Ikeda, Y., Hayashi, H., Okuda, N., \& Park, E. Y. (2007). Efficient cellulase production by the filamentous fungus Acremonium cellulolyticus. Biotechnology Progress, 23, 333-338. $\mathrm{http}: / / \mathrm{dx}$.doi.org/10.1021/bp060201s

Jaradat, Z., Dawagreh, A., Ababneh, Q., \& Saadoun, I. (2008). Influence of culture conditions on cellulase production by Streptomyces sp. (Strain J2). Jordan Journal of Biological Sciences, 1, 141-146.

Jeya, M., Nguyen, N. P. T., Moon, H. J., Kim, S. H., \& Lee, J. K. (2010). Conversion of woody biomass into fermentable sugars by cellulase from Agaricus arvensis. Bioresource Technology, 101, 8742-8749. http://dx.doi.org/10.1016/j.biortech.2010.06.055

Kim, J. K., Oh, B. R., Shin, H. J., Eomd, C. Y., \& Kim, S. W. (2008). Statistical optimization of enzymatic saccharification and ethanol fermentation using food waste. Process Biochemistry, 43, 1308-1312. http://dx.doi.org/10.1016/j.procbio.2008.07.007

Laopaiboon, L., Nuanpeng, S., Srinophakun, P., Klanrit, P., \& Laopaiboon, P. (2009). Ethanolproduction from sweet sorghum juice using very high gravity technology: Effects of carbon and nitrogen supplementations. Bioresource Technology, 100, 4176-4182. http://dx.doi.org/10.1016/j.biortech.2009.03.046

Levin, L., Herrmann, C., \& Papinutti, V. L. (2008). Optimization of lignocellulolytic enzyme production by the white-rot fungus Trametes trogii in solid-state fermentation using response surface methodology. Biochemical Engineering Journal, 39, 207-214. http://dx.doi.org/10.1016/j.bej.2007.09.004

Liu, J., \& Yang, J. (2007). Cellulase production by Trichoderma koningii AS3.4262 in solid-state fermentation using lignocellulosic waste from the vinegar industry. Food Technology and Biotechnology, 45, 420-425.

Mandels, M. (1975). Microbial Sources of cellulase. Biotechnology and bioengineering symposium, 5, 81-105.

Mandels, M., \& Weber, J. (1969). The production of cellulases. In Cellulases and their applications. Advances in Chemistry, 95, 391-414. http://dx.doi.org/10.1021/ba-1969-0095.ch023

Narasimha, G., Sridevi, A., Viswanath, B., Chandra, M. S., \& Reddy, B. R. (2006). Nutrient effects on production of cellulolytic enzymes by Aspergillus niger. Advances in Chemistry Series, 5, 472-476.

Olsson, L., Christensen, T. M. I. E., Hansen, K. P., \& Palmqvist, E. A. (2003). Influence of the carbon source on production of cellulases, hemicellulases and pectinases by Trichoderma reesei Rut C-30. Enzyme and Microbial Technology, 33, 612-619. http://dx.doi.org/10.1016/S0141-0229(03)00181-9

Paul, J., \& Varma, A. K. (1993). Hydrolytic enzymes production in Micrococcus roseus growing on different

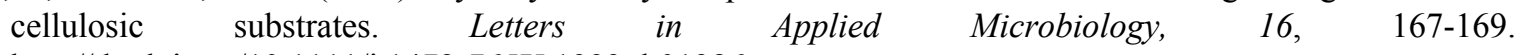
http://dx.doi.org/10.1111/j.1472-765X.1993.tb01386.x

Qi, B., Chen, X., Shen, F., Su, Y., \& Wan, Y. (2009). Optimization of enzymatic hydrolysis of wheat straw pretreated by alkaline peroxide using response surface methodology. Industrial Engineering Chemistry Research, 48, 7346-7353. http://dx.doi.org/10.1021/ie8016863

Singh, R., Kumar, R., Bishnoi, K., \& Bishnoi, N. R. (2009). Optimization of synergistic parameters for thermostable cellulase activity of Aspergillus heteromorphus using response surface methodology. Biochemical Engineering Journal, 48, 28-35. http://dx.doi.org/10.1016/j.bej.2009.08.001

Sukumaran, R. K., Singhania, R. R., Mathew, G. M., \& Pandey, A. (2009). Cellulase production using biomass 
feed stock and its application in lignocellulose saccharification for bio-ethanol production. Renewable Energy, 34, 421-424. http://dx.doi.org/10.1016/j.renene.2008.05.008

Sun, Y., \& Cheng, J. (2002). Hydrolysis of lignocellulosic materials for ethanol production. Bioresource Technology, 83, 1-11. http://dx.doi.org/10.1016/S0960-8524(01)00212-7

SzabÓ, I. J., Johansson, G., \& Pettersson, G. (1996). Optimized cellulase production by Phanerochaete chrysosporium: control of catabolite repression by fed-batch cultivation. Journal of Biotechnology, 48, 221-230. http://dx.doi.org/10.1016/0168-1656(96)01512-X

Taleb, A., Khadiga, A. A., Mashhoor, W. A., Sohair, A. N., Sharaf, M. S., Azeem, A., \& Hoda, H. M. (2009). Nutritional and environmental factors affecting cellulase production by two strains of Cellulolytic Bacilli. Australian Journal of Basic and Applied Sciences, 3, 2429-2436.

\section{Copyrights}

Copyright for this article is retained by the author(s), with first publication rights granted to the journal.

This is an open-access article distributed under the terms and conditions of the Creative Commons Attribution license (http://creativecommons.org/licenses/by/3.0/). 